\title{
Dermal Injectable Filler
}

National Cancer Institute

\section{Source}

National Cancer Institute. Dermal Injectable Filler. NCI Thesaurus. Code C157717.

A preparation consisting of absorbable or non-absorbable materials, or harvested autologous fat, that may be injected into certain areas of tissue to minimize skin depressions, scars, and signs of aging. Absorbable materials, which include collagen, hyaluronic acid $(\mathrm{HA})$, calcium hydroxylapatite $(\mathrm{CaHA})$, and poly-L-lactic acid (PLLA), tend to have more temporary effects, whereas the effects of non-absorbable materials, such as polymethylmethacrylate (PMMA) microspheres, tend to be more permanent. 